\title{
Life and Death in America: \\ The Killing of Amadou Diallo
}

Charles Huckelbury

Justice is the end of government.

(James Madison, The Federalist \#51)

It is the madness of folly to expect mercy from those who have refused to do justice.

(Thomas Paine, The American Crisis \#1)

little after midnight on February 4, 1999, Amadou Diallo was standing
in the entry to his apartment in New York City. Mr. Diallo had committed
neither felony nor misdemeanor; he was a West African immigrant and
street vendor without criminal history who had come to the United States
believing the promise of Emma Lazarus's poem engraved on the Statue of
Liberty. He was not wearing a mask, and he was not displaying a weapon.
In short, he was not doing anything remarkable to distinguish him from any
other citizen. He had not, however, considered two liabilities that put his
liberty in danger and ultimately cost him his life: he was black and living in
the wrong part of the city.

As Mr. Diallo stood in his vestibule looking out on the street in front of his apartment, he was approached by four white policemen-all were members of the Street Crimes Unit, a special tactical squad emphasizing the identification and arrest of neighbourhood thugs. None of the police officers were in uniform, and all were large, intimidating, muscular men with the requisite attitude for doing their job - which is to say, they looked for trouble, expected to find it, and did not mind so much when they did.

As testimony subsequently revealed, the police officers were looking for a black rapist, and Diallo had the misfortune to be black and living in the same area where the suspect committed his crime. Moreover, one of Diallo's neighbours had called police and reported that he (Diallo) was acting "suspiciously." Thus, when the four officers approached Mr. Diallo, they were primed.

When all four were within approximately ten feet from Diallo, they reportedly identified themselves as police officers and ordered him not to move. Unaccustomed to being accosted by the police, Mr. Diallo responded reasonably to the officers' presence and verbal order by attempting to 
withdraw his wallet from his hip pocket, presumably to offer identification. As soon as the wallet was out of his pocket, one of the police officers yelled "Gun," and all four men drew their weapons and opened fire on the unsuspecting immigrant. Forensic evidence revealed that the officers fired forty-one times, with nineteen rounds striking Diallo, at least two of which entered the bottom of his feet as he lay on the floor of the vestibule. He was dead in seconds.

In and of itself, the killing of Amadou Diallo would have been tragic enough. Four police officers gunning down an unarmed and totally innocent man, while not unheard of in this country, certainly should have provoked enough outrage and re-examination of police policy to ensure that such a profound blunder would not happen again, or at the very least, that the chances for such a catastrophe would be greatly diminished. The tragedy was compounded, however, by the subsequent testimony at trial of the four officers indicted for Diallo's murder. Not only was Amadou Diallo sent to a premature grave by representatives of the government, he was made complicit in his own death, and the men who killed him walked out of the courtroom and returned to their families and jobs.

Revisiting the accounts of Diallo's behaviour that night, it is noteworthy that during the initial investigation, he was not accused of doing anything that might have provoked such a vicious fusillade. He was not a wanted criminal, and he had no prior record. He earned a living as a street vendor, and he was doing nothing more threatening than standing in his own vestibule looking at the activity in the street. A rational person would think that anyone standing on his or her own property, observing the street, would not present a threat requiring forty-one rounds of ammunition. Diallo was simply a reportedly "suspicious" person.

The vestibule where Diallo stood was well lighted, and he attempted to do what any right-thinking citizen would do when confronted with four aggressive police officers; he unhesitatingly tried to present identification, a standard but offensive requirement when demanded in this day of no-nonsense law enforcement and unrestricted police license. That is, by any objective standard, Amadou Diallo did absolutely nothing to precipitate his death. Indeed, so innocent was Mr. Diallo that one of the police officers at the scene cradled his head after the shooting and begged him not to die, a rather disingenuous request, considering that same police officer had just done everything in his power to kill him. And then came the trial testimony. 
Journal of Prisoners on Prisons, Volume 11, 2001

The police officers all took the stand in their defense and described a series of events that night that shifted the blame for the tragedy directly onto Diallo's cold, dead shoulders. It was the felonious equivalent of finding him guilty of the tort offense of contributory negligence in his own death. By the time they got to trial nearly a year later, the police officers told a cohesive version of what had happened that night. Now the vestibule became "dimly lighted." Diallo was acting like a suspect, here defined as being black and looking first in one direction, then the other. When the four officers approached him, at least one held out a badge for identification and "asked" to talk to Diallo. (Only in Colorado after JonBenet Ramsey's murder have the police ever requested an interview.) According to the officers' trial testimony, Diallo responded by moving back into the recesses of his apartment's vestibule and reaching for his hip pocket. Ignoring shouted commands to show his hands, Diallo adopted a "combat stance" and pulled his wallet.

As soon as the wallet was visible, one of the officers mistakenly identified a firearm and screamed a warning to his companions. At this point, one of the other police officers apparently tripped and fell to the ground, thereby, according to testimony, leading the other officers to believe that he had been shot by Mr. Diallo. It was never sufficiently explained how the police officer who tripped could have been shot when there was neither sound of a gunshot nor sign of a muzzle flash from a weapon. Nevertheless, all four officers began firing wildly at Diallo. Only after he was dead and a search begun for the weapon did the police discover the magnitude of their mistake. Thus began the futile attempts to stanch the flow of blood from the nineteen holes in Amadou Diallo's rapidly cooling body.

The officers also tried to explain away the number of shots fired by testifying that the sparks from the many ricochets from their own gunfire made them believe that Diallo was returning fire, thus provoking an even more intense response from the police officers. For those who have watched action movies starring Mel Gibson or Sylvester Stallone, ricochets perhaps do spark off everything from car fenders to modeling clay, but that is Hollywood's version (like the laser duels in Star Wars) and bears no resemblance to reality. Amadou Diallo's building was brick and wood. Lead striking wood is absorbed; lead striking brick is indeed deflected but without producing a spark that would indicate the bullet's striking another metal. In other words, there could not have been any sparks that night because wood and brick do not generate them when struck by expended pistol rounds. 
Did the police lie or were they simply mistaken in their abject terror in the presence of what they thought was an armed adversary? Twelve men and women heard the testimony, twelve men and women who had never been close to a shoot-out and would not know gunfire from a backfire, and they held that the killing of Amadou Diallo was justified.

It is not the purpose of this essay to determine whether the police officers embellished their story or if they truly believed a lone unarmed man was attempting to kill them by firing even more rapidly than four of them in concert were capable of. What I would like to explore here is another, more pernicious explanation that runs parallel to the truth about the shooting and involves the attitude instilled and nurtured in police departments in general and in tactical units specifically that promotes tragedies like the killing of Amadou Diallo. It is the intense militarization of the police over the past two decades that has culminated in the belief by the men and women who work the streets that they are indeed soldiers operating with the same rules of engagement that govern armed forces overseas. And it is this precise attitude that causes police officers to view citizens of this country, citizens who have done nothing illegal, as threats in the domestic equivalent of a free-fire zone.

Like any competent combat unit, police tactical squads develop an esprit de corps that promotes overreaction when confronted with a hostile or dangerous situation. The tactical advantages of massive firepower are currently taught in police academies, and the officers in the Diallo killing testified that they had been instructed to empty their weapons in a gunfight. Tactical officers also expect trouble, similar to soldiers on a combat patrol. And, if the truth is not too harsh, these men and the occasional woman not only anticipate confrontation - they look forward to it. After all, it is why they train, and like any good combat unit, the training is only preparation for the real thing, in this case, armed confrontations on the street. Compounding the situation is the racial distribution of these tactical squads; most are predominately or exclusively white, while their anticipated adversariesand this is fundamental to the results - are predominately or exclusively people of color. Add to that the adrenaline surging during such an encounter, and you have a recipe for disaster.

Tragedies like Amadou Diallo's killing, therefore, are virtually guaranteed, given the number and nature of these tactical units deployed in police departments around the country. But the John Wayne attitude is not limited 
to members of SWAT teams. In Louisville, Kentucky, for example, two white police officers shot and killed Desmond Randolph, a black teenager, for revving the engine of the stolen car he was driving. ${ }^{1}$ In California, police officers surrounded the car of a sleeping teenager, also black. After first trying and failing to wake her, the police then attempted to break the driver's window. The teenager instinctively reached for the pistol lying in the seat beside her, which provoked the police into shooting her more than a dozen times in the head and upper torso. ${ }^{2}$

The officers who work the tactical units are volunteers, all of whom undergo both physical and psychological training in preparation for their mission, and notwithstanding the professed remorse of the defense witnesses in the Diallo case, these officers see that mission in the same terms that infantry units in the armed forces approach theirs: maximum firepower in the face of armed resistance, or in Amadou Diallo's case, suspected armed resistance.

This is not to say that police officers should be naïve enough to trust exclusively in the good faith of the men and women they are hired to protect and serve, if I may be permitted such an anachronism. Indeed, "bad guys" still roam the streets in certain areas, and all law enforcement personnel should be alert to the potential for danger. The stark facts, however, demonstrate that the risks are exaggerated and criminal defendants usually surrender rather than engage in shoot-outs with police. In fact, in any given year, police work is consistently absent among the top ten jobs in terms of mortality and injury rates. Cab drivers, lumberjacks, firefighters, and commercial fishermen all have higher rates of on-the-job deaths than police officers. Indeed, in 1999, the latest year for which statistics are available, cabbies suffered on-the-job deaths at a rate of 30 per $100,000 .^{3}$ Police

1 The officers fired twenty-two times at Randolph, killing him instantly. The chief of police praised the two officers during an awards ceremony (Exceptional Valor Award) for their prompt reaction. The Chief was subsequently fired by the mayor for his "insensitivity" ("Fatal shooting, delayed fallout roil Louisville," USA Today, March 29,2000 , v. 18 n. 139 , p. 8A).

2 The officers were subsequently cleared of the shooting. They all claimed they were in fear for their lives, although they did admit they could have found a less alarming way to examine the young woman, Tyisha Miller ("Fatal Judgement," People, October 11, 1999, v. 52 n. 14, p. 143-9).

3 "Cabbies face fears with every fare," USA Today, May 2, 2000, p. 3A. 
officers, by comparison, died at a far lesser rate of 6.8 per 100,000, slightly less than retail-sales clerks at 6.9 per 100,000.

Moreover, the percentage of police officers actually killed by armed assailants generally comprises about half of all deaths, the others coming as a result of heart attacks, traffic accidents, suicides or other causes. So a simple statistical analysis demonstrates that the dangers purportedly inherent in police work are overrated, even in the face of counter-claims by police organizations and television shows like COPS and America's Most Wanted.

So why have police departments militarized their tactical units, and even their traditional patrol units, to such an extent? What is the justification for going among innocent citizens with a gunfighter's mentality, not only expecting to engage an armed adversary but welcoming the showdown? The answer lies partially with the self-interested promotion of politicians and certain law enforcement executives, but the other half of the equation is a confluence of public and law enforcement opinion that marginalizes individuals like Amadou Diallo and sets them up for victim status. And, sadly, American society as a whole has participated in an invidious particularism that contributes to the mutual animosity between the police and certain ethnic groups.

The particularist school of political theory allows each group (like the police) within society the right to promote its own self-interest without regard for the interests of other groups, no matter how large or small. The emphasis is therefore on group survival, rather than a stronger, healthier gestalt. Pluralism, in contrast, recognizes each group's development within a larger framework of common society. As Diane Ravitch explains it, "Instead of promoting reconciliation and a sense of shared community, particularism rekindles ancient hatreds in the present; its precepts set group against group. [Adherents] learn that it is appropriate to think of others primarily in terms of their group identity." ${ }^{4}$ That is, individual merit and identification are subsumed within the group to which that individual belongs, relieving the "foreign" observer and group member of the responsibility for objective assessment of any other group's members.

To demonstrate, hyphenated Americans have now become the rule rather than the exception, and although ethnicity can and should be a source of

4 Quoted in David Shipler, A Country of Strangers, Black and White in America. (New York: Knopf, 1997) p. 225. 
pride, it can often function as a line of demarcation, separating citizens of heterogeneous backgrounds who would normally form a cohesive unit. Black Americans and immigrants of African descent, like Amadou Diallo, tend to close ranks in what they see as a self-preservation effort to stave off assimilation by a biased (and often oppressive) Eurocentric culture. That is, as society has become more ethnically self-aware, de facto segregation has become resurgent as racial and cultural enclaves seek to distinguish themselves and their values from mainstream lifestyles, situations in which they feel at once alienated and mistrustful. It is this fragmentation of contemporary American society that permits an unexamined subculture to avoid accountability and encourages the police, acting within their own group, to engage in the same kind of particularist philosophy as the people they observe on the street. Given their training and indoctrination in terms of this particular zeitgeist, police officers could hardly be expected to react to hostile situations, either perceived or actual, with other than immediate and deadly force against a particularized enemy, notably people of color.

Contrary to the almost apathetic attitude of white respondents, black Americans consistently identify racism as a primary concern and expect it in their daily encounters with white society. The deplorable condition of many predominantly black schools versus upscale white facilities; the lack of health care for the working poor and those on welfare; and the disproportionate number of black and Hispanic citizens in prison all contribute to an us-versus-them mentality, displayed in anti-establishment music, dress, and behaviours, whether in the street or on the athletic field. Conservatism, whether compassionate or the other, more common variety, encourages this separation with its retrenchment or elimination of affirmative action, for example, and its perceived favouritism of the more affluent (read "white") members of society.

Law enforcement therefore becomes, in the eyes of the multicultural segments of society, a tool of the affluent, of the same constellation of predominately white males who make the laws that minorities see, rightly or wrongly, as depriving them of both their rights and their identities. Minority populations react by withholding the traditional respect extended to the police that white society (and the police themselves) expects and often demands. The police concomitantly view these autonomous displays as a rejection of the mores (and often the laws) that define the majority, which in turn produces the suspicion and anticipation that makes firearms the first response in the field. The corollary, of course, is that the police begin to reflect the majority's 
response to the minorities' demands: they see themselves as under-appreciated and misunderstood. They become resentful, aware of the latent hostility they face each day and paranoid in the face of any encounter, especially with people of color. They close ranks within their group and identify, as Ravitch described, other group members on the basis of external factors relating to that group's membership. A recent study of the Miami-Dade (Florida) police department confirms this analysis.

Geoffrey Alpert and Roger Dunham examined use-of-force reports for the years 1996-1998 and classified the incidents according to the race of the officers and civilians involved. The statistics demonstrate that when both police officer and arrestee were white, force was used in twenty-six percent of the reported cases. When the officer was black and the arrestee was white, force was required in sixteen percent of the cases. The study further disclosed that white police officers used force against black arrestees in forty percent of incidents, compared to sixty-seven percent when both officer and arrestee were black. ${ }^{5}$ Chuck Wexler, the executive director of the Police Executive Research Forum, hailed the results following the Diallo trial as proof that use of force occurred more in intraracial arrests than during interracial confrontations, thus putting the lie to accusations that the police were inherently racist. ${ }^{6}$ After all, if police officers were more prone to use force on members of their own race, then Amadou Diallo's killing could not be characterized as a racist response by white police officers.

Wexler, however, misses the point. Although intraracial force was more common than interracial force, the ineluctable conclusion of the study, a study accepted by Wexler and his organization, is that black arrestees were subjected to the use of force far more than their white counterparts in similar situations. The racist or particularist response to this study would be that blacks are more violent and tend to resist arrest in more statistically significant numbers than whites. The more obvious conclusion is that black suspects are more likely to evoke a forceful response from the police, and that distinction is crucial.

The intuitive leap is therefore to assume that the police expect violent confrontations with black defendants and in general diminish the importance

5 "Measuring and Assessing Police Use of Force and Suspect Resistance." 1998. United States Department of Justice.

6 USA Today, March 13, 2000, p. 4A. 
of black lives, thus leading to unnecessary fatalities like the killing of Amadou Diallo. But what if the police are victims of a psychological campaign to isolate them from society in general and minority society particularly? Consider: In 1999, forty-two police officers were feloniously killed in the line of duty, fewer than in any other year since the FBI began keeping statistics in 1963. But instead of welcoming the good news that America's streets are steadily becoming less violent, James Pasco, the executive director of the Fraternal Order of Police, the nation's largest police union, responded by asserting, "It's not getting safer for law enforcement. Absolutely not There is a far greater disposition to attack law enforcement officers than there ever has been," 7 this at a time when overall crime has decreased for eight consecutive years. In other words, the police officers in the street are not being told the truth, not even by their own; they are being manipulated for personal benefit, a pernicious and vicious abuse of power that advocates an apocalyptic view and places those officers at higher risk for escalating confrontations in which they could be injured or killed.

Thus, statistical analyses such as those by Alpert and Dunham prove what the prisons confirm: that society and its judicial enforcement arm have also been the victims of a massive disinformation campaign. Americans, after all, love illusions, whether in their movies, televisions, or print media, and vested interests, including law enforcement, respond by identifying, cultivating, and maintaining an audience in order to provide what that particular group desires. This is the result of the current fragmentation of American society, a Diaspora of sorts that banishes people of color to the fringes and keeps them there, not necessarily economically or even socially constrained, but in a perceptual sense that they are somehow not one of us.

To eliminate this mutual, reactive misunderstanding, it will become necessary to drop the shields each side instinctively carries and to move toward a more pluralistic social environment, that is, one in which police and civilians look beyond group identities to establish common ground. The current emphasis on community policing is a correct step in promoting empathy, a quality sadly lacking in police academies and minority neighborhoods. But simply putting police in certain geographical areas will not eliminate the problem; the four police officers who killed Amadou Diallo were on the street in a very real sense but unconcerned with establishing

7 "Number of police slain drops to record low." USA Today, May 16, 2000, p. 4A. 
community relations, and the anonymous caller who described Diallo's behavior as suspicious clearly was hostage to a stereotypical bias.

As the start of a remedy, there needs to be a dialogue between the majority and the minorities with the police as an active participant. Without some sort of regularly held symposia, in which all sides voice their concerns in an atmosphere of candor and trust, and in which accurate information is available to all, the fragmentation I have described will continue apace, all sides refusing to accept responsibility and declining to treat each other as worthy but fallible human beings. We are not combatants staring at each other's battle lines across some DMZ; it is time everyone stopped playing these dangerous roles.

The militaristic, confrontational attitude of today's urban police departments is anachronistic and does more harm than good. Although it focuses on quickly overcoming armed opposition and preserving the line officers' lives, it has resulted and will continue to result in needless civilian casualties in a specious war whose justification has expanded incrementally over three decades. The tragic paradox is that as America's streets have become progressively safer for everyone, contacts between civilians and police have become increasingly deadlier, due largely to subjective evaluations encouraged by disinformation campaigns like that of James Pasco.

America is not and never has been the "melting pot" of its reputation, but surely it must remain a republic in which, as James Madison observed, justice is the end, and in which citizens of any color or creed can safely walk the streets without fear of urban predators on either side of the law. If American society is a weave of ethnic and religious patterns, then we are all part of the same tapestry, deserving of the same respect and recognition. Just as it is certainly wrong for citizens to fire on the police, it is not unreasonable for all law-abiding citizens, no matter what their color, to demand the same consideration in return.

Charles Huckelbury is a regular contributor to the $J P P$, and has recently been appointed to the editorial board. He can be contacted at New Hampshire State Penitentiary, P.O. Box 14, Concord, New Hampshire 03301, U.S.A. 